\title{
'A Gigantic Pedagogical Leap': The Process of Shifts during Three Learning Study Projects in Swedish Early Childhood Education
}

\author{
Agneta Ljung-Djärf ${ }^{1}$, Eva Wennås Brante ${ }^{1,2} \&$ Mona Holmqvist Olander ${ }^{1,2}$ \\ ${ }^{1}$ School of education and environment, Kristianstad University, Kristianstad, Sweden \\ ${ }^{2}$ Department of pedagogical, Curricular and professional studies, University of Gothenburg, Gothenburg, \\ Sweden \\ Correspondence: Agneta Ljung-Djärf, School of education and environment, Kristianstad University, \\ Kristianstad, Sweden.
}

Received: July 31, 2013 Accepted: August 13, 2013 Online Published: October 21, 2013

doi:10.11114/jets.v2i1.186 URL: http://dx.doi.org/10.11114/jets.v2i1.186

\begin{abstract}
Swedish early childhood education (ECE) offers a curriculum-based preschool for children aged one to five, and a preschool class for children aged six years. Activities in these programs have traditionally been based on play and having fun, avoiding structured activities with formal learning objectives. Due to indications that Swedish ECE has failed to use its resources to stimulate children's learning, the revised ECE curriculum now contains discernible learning objectives. This study analyses the process by which preschool teachers shifted their emphasis when participating in an learning study based on three projects conducted in Swedish ECE practice. In total, 14 preschool teachers, 95 children (2-6-year-olds), and five researchers participated. The objects of learning were: (1) 3D geometrical forms (2-3-year-olds), (2) organic decomposition (4-5-year-olds), and (3) the concept "twice as" (6-year-olds). The empirical material comprises 278 pre-, post-, and delayed post-tests, twelve planning meetings, and nine teaching activities. The results indicate that, during the projects, the initial focus on mere play expanded to include a focus on the object of learning. Three modes of change were discerned in how (1) the activities were framed, (2) the learning was perceived, and (3) the learning activities were conducted.
\end{abstract}

Keywords: learning study, variation theory, early childhood education, play and learning

\section{Introduction and Aim}

The current Swedish school system offers curriculum-based early childhood education (ECE) for children aged one to five and a preschool class for children aged six years. The preschool activities are characterized by qualitative discussions with care, nurturing, and learning as their starting points. The intention is to create a playful and educational environment for children based on the child's perspective (Pramling Samuelsson \& Asplund Carlsson, 2003; Sommer, Pramling Samuelsson, \& Hundeide, 2009).

In Swedish ECE practice, activities have traditionally been based on play and having fun, avoiding structured activities with formal learning objectives. The strong focus on play, which is understood as fundamental and critical to children's development (see, e.g., Fleer, 2010, 2011; Lillemyr, Söbstad, Marder, \& Flowerday, 2011; Pramling Samuelsson \& Fleer, 2010), is deeply ingrained. Play is more or less seen as the same as early childhood education (Ailwood, 2003) and is often described as a prerequisite for children's development and learning (see, e.g., Fleer, 2010, 2011; Lillemyr et al., 2011).

Children's play and teachers' exploitation of it for learning has a long tradition, has been and remains a fundamental part of the Swedish ECE mission. However, this tradition has been criticized for fostering a preschool 'doing culture' focused on what to do instead of on what to learn (Pramling Samuelsson \& Pramling, 2008) and thereby not concretizing the learning content.

In response to indications that Swedish ECE has failed to use its resources to stimulate children's learning (Swedish National Agency for Education, 2004), the revised preschool curriculum now contains discernible learning objectives (Swedish National Agency for Education, 2010). The revised curriculum clarifies the ECE educational mission, and content issues have now become increasingly prominent. However, these increased 
expectations that children should learn specific and defined content have raised concerns that 'school type' teaching methods may displace the play-based practices of preschool (Lidholt, 2001). One way to address such concerns has been to rhetorically connect play with ECE learning, play even being described as ECE learning: play is regarded as fundamental to children's learning and development rather than an aimless pastime.

The implications of a combination of play viewed as learning and a more specific content emphasis are left to the preschool teachers to handle. This is challenging, not least because the Swedish ECE tradition, as briefly described above, is not systematic or goal-oriented in terms of developing children's abilities or knowledge (Pramling Samuelsson \& Pramling, 2008), because accessible theories of play were not developed with the intention of accommodating increased demands for learning content (Fleer, 2011). The lack of theoretical tools to support greater requirements for more specific and defined content poses a challenge. Our concern is to find out whether and how the learning study (LS) model can help ECE teachers direct their attention towards content issues and rethink learning as a more explicitly defined process than something that, more or less, automatically happens whenever the child is playing or being active. The aim is to analyse the process by which preschool teachers shifted their emphasis when participating in an LS based on three projects conducted in Swedish ECE practice. In this way, this study is about the use of LS methodology to challenge assumptions about learning and to develop tools useful when discussing and emphasizing ECE content, not instead of, but in addition to, children's play.

\subsection{Learning Study and Variation Theory}

A learning study is a kind of action research (Elliott, 1991) intended to develop teacher professionalism and involving close cooperation between teachers and researchers. The LS model combines a theory of learning, i.e., variation theory (see, e.g., Lo, 2012; Lo \& Marton, 2012; Marton \& Booth, 1997), with the concept of lesson study (see, e.g., Lewis, 2002; Yoshida \& Fernandez, 2004). The studies reported here used variation theory concepts beforehand when planning the interventions, during the interventions, and afterwards when discussing and evaluating the interventions. Teachers were introduced to variation theory in a theoretical way and by implementing it directly in their teaching practice.

A main characteristic of variation theory is that it aims to identify the critical aspects of an object of learning. The critical aspect of an object of learning is related both to the people who experience it and to the object of learning itself, and as each person has somewhat different pre-knowledge of a specific phenomenon, diverse aspects of it may be critical. A critical aspect can be varied against a background of sameness using patterns of variation. Such variation can also be attained by pointing out what something is by demonstrating what it is not. The experienced variation enables discernment of the critical feature from the phenomenon: it 'stands out' from the background and we can become focally aware of it. We call this process opening a dimension of variation, which allows critical aspects to be discerned (Runesson \& Mok, 2003).

Let us exemplify with an object of learning; 3D geometrical forms (see also Holmqvist Olander \& Ljung-Djärf, 2013). This object of learning has many aspects, and the example treated here is limited specifically to the cylinder and the cubicle. Empirically, the critical aspects of an object of learning are always identified by the researcher working together with a student or group of students; in the present case, a group of two- and three-year-old children are to learn about the differences between these forms. They have no knowledge of the names of these forms and few words to describe them. What are the features of this critical aspect? One form is round and the other is 'pointy or square', and one form rolls smoothly whereas the other does not. These are the aspects that we must vary against a background of sameness in order to make them discernible and thus possible to experience in order to form a new understanding of the object of learning (i.e., different geometrical 3D forms). Lo (2012) emphasizes the interrelatedness of critical aspects and features, making it impossible for a person to discern a critical feature without knowing the related critical aspect. The critical aspect for children who do not yet perceive differences between how forms move is that round things roll smoothly while cubicles do not. Children must focus simultaneously on roundness and squareness in order to decide whether or not a form will roll smoothly. To summarize, learning can occur when critical aspects are discerned, which is possible when a dimension of variation is opened around that critical aspect by simultaneously contrasting the features of the aspect along the dimension of variation. These contrasts cannot be designed without knowing who the learners are. The main concepts of variation theory are outlined in Table 1. 
Table 1. Main concepts of variation theory

\begin{tabular}{ll}
\hline Object of learning & $\begin{array}{l}\text { The focus of learning. Learning is always about something. An object of learning, or } \\
\text { phenomenon, consists of many aspects. Not all can be in focal awareness at the same time. }\end{array}$ \\
\hline Critical aspect & $\begin{array}{l}\text { Empirically based, established in cooperation with a learning person or group considering an } \\
\text { object of learning. Critical in that it renders a new understanding of the learning object once } \\
\text { discerned; remains critical until discerned in the object of learning. }\end{array}$ \\
\hline $\begin{array}{l}\text { Dimension of } \\
\text { variation }\end{array}$ & $\begin{array}{l}\text { When features or values of the critical aspects are varied we say that we open a dimension of } \\
\text { variation of the critical aspect. }\end{array}$ \\
\hline Pattern of variation & $\begin{array}{l}\text { The features should be varied systematically in order to be discerned. This should contain } \\
\text { both parts that vary and parts that remain unvaried and can comprise patterns of separation, } \\
\text { generalization, or fusion. }\end{array}$ \\
\hline Separation & $\begin{array}{l}\text { To experience the difference between two features or values is to experience a contrast. } \\
\text { When contrasts are experienced it becomes possible to separate the feature from the object it } \\
\text { belongs to and to focus on it, not the whole object. }\end{array}$ \\
\hline Generalization & $\begin{array}{l}\text { One feature is kept in focus while not being varied, while other features vary, in order to } \\
\text { extract the meaning of the unvaried feature. }\end{array}$ \\
\hline Fusion & $\begin{array}{l}\text { By varying several critical aspects, a new understanding of the parts and whole of an object } \\
\text { of learning is made possible. }\end{array}$ \\
\hline
\end{tabular}

The LS model is an iterative process in which a group of teachers and researchers plans and evaluates a series of lessons/activities targeting the same object of learning, the goal being to improve the teaching with the aid of variation theory concepts. LS projects typically comprise three cycles of four specific steps each. The structure of the steps remains the same, but the method of implementation changes during the process. The first step is to analyse ways of discerning aspects of the chosen object of learning. This is based on the results of a screening (in cycle A) or the test results of the previous cycle (in cycles B and C). The participants evaluate and discuss whether or how the children's learning and understanding may have changed, and what aspects of the object of learning still seem to be difficult for the children to grasp. The guiding principles of this analysis and discussion are the variation theory concepts of discernment, simultaneity, and variation. An initial (in cycle A) or developed (in cycles B and C) teaching activity is designed. The second step is to discover what the pupils participating in the first cycle already know about the intended object of learning; this step is called the pre-test. The pre-test results are analysed qualitatively, and are quantified based on predetermined criteria. The third step is for one of the participating teachers to implement the teaching activity. The fourth step is to use a post-test to investigate differences between the children's understanding before and after the teaching activity. These changes are analysed and used as the basis of further work. The next cycle starts with an analysis meeting (step 1) in which a new lesson is planned, aiming to foster even better discernment of critical aspects, followed by another pre-test (step 2), a second teaching activity conducted by another teacher in another group of children (step 3), and a post-test (step 4). All parts of the process are documented. Usually each group of children is given a delayed post-test after a few weeks (see, e.g., Holmqvist, 2011; Lo, 2012). The LS process is summarized in Figure 1.

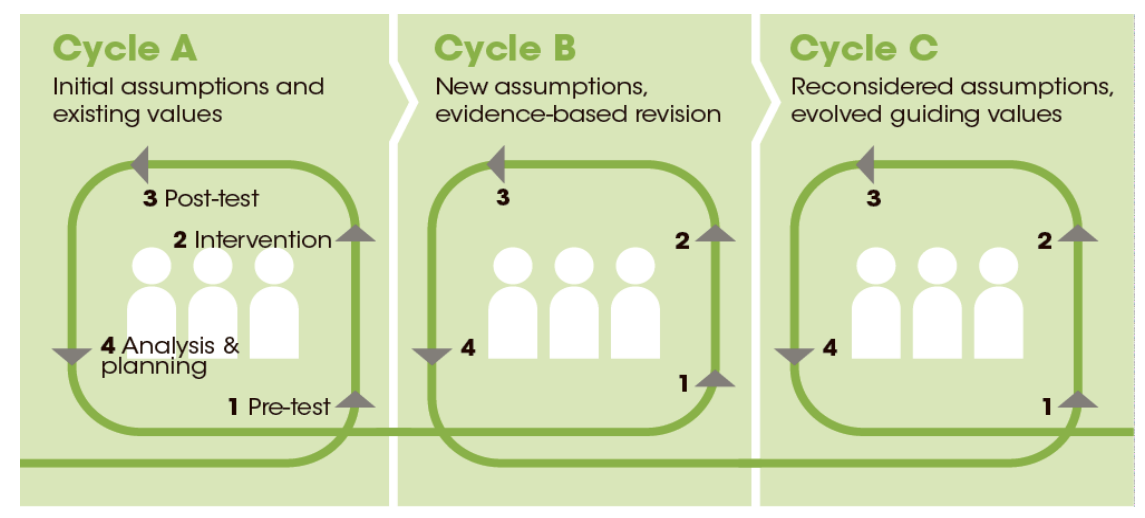

Figure 1. Design of learning study cycles (Ljung-Djärf, Magnusson, \& Peterson, 2013)

\subsection{Some Previous Research}

International peer-reviewed studies of the use of LS as a tool for educational development examine various 
primary and compulsory school contexts. The body of research is extensive and comprises mainly studies from various European (see, e.g., Olteanu \& Holmqvist, 2012; Olteanu \& Olteanu, 2010, 2012; Runesson \& Gustafsson, 2012) and Asia countries (see, e.g., Andrew, 2012, Pang, 2006; Pang \& Marton, 2005; Siu, 2008; Tang \& Leung, 2012; Wood, 2013; Yuk, 2012). Since 1990, several hundred LSs have been implemented and evaluated. Overall, the LS model has been demonstrated to improve learning, reduce the gap between high and low achievers, and improve teachers and researchers knowledge of teaching and learning (Lo, 2012; Lo \& Marton, 2012).

Knowledge of how the LS model can be adapted for use in ECE practice is still developing. During the last years, some initial results based on LS projects conducted in Swedish ECE practice have been internationally published. These studies have analysed children's and teachers' learning (see e.g., Holmqvist, Brante, \& Tullgren, 2012; Holmqvist, Tullgren, \& Brante, 2010, 2011, 2012; Ljung-Djärf, 2013; Ljung-Djärf et al., 2013). The results of these studies are similar to those of international LS research in primary and compulsory school settings, as mentioned above, i.e., LS methodology helped teachers be more precise and direct in describing the object of learning, better apprehend the children's perspective, and incorporate new dimensions into the learning situation.

The results also indicate that the LS model can be applied and adapted to Swedish ECE settings to deepen teacher understanding of children's learning (Ljung-Djärf et al., 2013). However, there are some challenges to the model, which needs adaptation to suit the ECE culture and context as well as young children's conditions and needs in terms of: (1) the approach to learning, (2) ways of guiding the children, (3) the content the teachers emphasize, and (4) ways of assessing learning outcome (Ljung-Djärf \& Holmqvist Olander, 2013).

The results of these initial studies suggest that variation theory can serve as a guiding principle in ECE pedagogical design, for example, in the case of how contrasting critical aspects of the object of learning can be used to improve children's discernment of the mathematical concept 'twice as' (Ljung-Djärf, 2013). By letting different aspects related to the intended object of learning be variant or invariant, different patterns of variation can be used in developing the interventions. The results indicate differences related to the children's learning in each of the three cycles. This suggests that the conscious use of simultaneity and contrast of identified critical aspects can successfully stimulate children's short- and long-term learning (Ljung-Djärf, 2013). A similar conclusion was drawn by Ljung-Djärf, Holmqvist Olander, and Wennås Brante (2013) from the project on 'twice as' and in five other studies of the use of patterns of variation designed by variation theory as a way to challenge and develop Swedish ECE practice. Each project is a concrete example of the use of patterns of variation to improve early childhood learning. In all cases, a tendency for qualitative changes in children's ways of discerning aspects of the object of learning could be noted. The analysis also highlighted that the teachers sharpened their focus on content issues and consciously used children's meaning making as an indicator of potential critical aspects when creating and capturing learning situations. By that, the LS model were suggested to be a substantial contribution to coordinate the children's and teacher's perspective to a shared object of learning, enabling them to continue with their mutual learning activity (Ljung-Djärf, Holmqvist Olander, \& Wennås Brante, 2013).

A critical aspect of teacher application of the LS model is to understand and use the core concepts of variation theory. Holmqvist Olander and Ljung-Djärf (2013) analysed 24 preschool teachers' ways of implicitly and explicitly applying the framework of variation theory, introduced in in-service training on the use of LS in ECE. Participation in the training entailed conducting literature studies, theoretical discussions, and practical work in the form of an LS project focusing on the teachers' own ECE practices. The results indicated that all teachers understood and applied the meaning of the 'variation' concept, i.e., variation of aspects of the content rather than the methods. Half of the teachers also applied the concepts of variation theory properly, although not required to do so. In total, 12 of 24 participants used the concepts from the theoretical framework, namely, object of learning, critical aspects, variation, simultaneity, and discernment (Holmqvist Olander \& Ljung-Djärf, 2013).

In sum, previous research suggests that the LS model can be used to develop Swedish ECE learning by building on, re-evaluating, and expanding children's experiences, and by helping teachers (1) focus on and contrast critical aspects of an object of learning and (2) reflect on the use of play, imagination, and concepts and on directing the children's attention when doing so (see, e.g., Ljung-Djärf et al., 2013; Ljung-Djärf, Holmqvist Olander, \& Wennås Brante, 2013). However, although previous studies have produced promising results, further LS research into ECE practices is warranted.

As mentioned, the aim of this current study is to contribute by analysing the process of Swedish preschool teachers' shift in emphasis when participating in an LS. The analysis is based on three LS projects conducted in Swedish ECE practice. 


\section{Conducting the Study}

The projects were conducted in four Swedish preschools and three preschool classes in 2010 and 2011. The objects of children's learning examined in the studies were: study $1-3 \mathrm{D}$ geometrical forms, study 2 - organic decomposition, and study 3 - the 'twice as' concept. Study 1 was conducted in three preschools, study 2 in one preschool, and study 3 in three preschool classes.

Ethical considerations, as described by The Swedish research council (2011), guided the process. All participants including parents, teachers, management, and children were informed about the aims of the study, the use of the data, and their rights to confidentiality and to withdraw from participation. During the interviews the young age of the children was taken into consideration. It was for example always voluntary to participate and if any child wanted their preschool teacher to be present in the room, it was arranged. We also tried to be sensitive to the children's ways expressing oneselves. This meant that the interviews sometimes also contained topics far removed from the intended focus. This sensitivity was seen as necessary and valuable to get the children to also express themselves on what was intended. Pictures of the children used in presentations have blurred faces to ensure anonymity; Table 2 summarizes the participants.

Table 2. Participants

\begin{tabular}{llll}
\hline & $\begin{array}{l}\text { Teachers } \\
(n=14)\end{array}$ & $\begin{array}{l}\text { Researchers } \\
(n=5)\end{array}$ & $\begin{array}{l}\text { Children } \\
(n=95)\end{array}$ \\
\hline Study 1: 3D geometrical forms & 4 & A \& B & $2-3$ years old $(n=25)$ \\
Study 2: organic decomposition & 5 & C, D, \& E & $\begin{array}{l}\text { 4-5 years old }(n=26) \\
\text { 6 years old }(n=44)\end{array}$ \\
Study 3: 'twice as' concept & 5 & $\mathrm{C}$ & .
\end{tabular}

The empirical material is mainly video-recorded and comprises records of twelve meetings, nine interventions, and 278 tests in the form of individual pre-, post-, and delayed post-tests (Table 3).

Table 3. The empirical material for each study

\begin{tabular}{llll}
\hline & $\begin{array}{l}\text { Meetings } \\
(n=12)\end{array}$ & $\begin{array}{l}\text { Interventions } \\
(n=9)\end{array}$ & $\begin{array}{l}\text { Pre-, post-, and delayed post-tests } \\
(n=278)\end{array}$ \\
\hline Study 1: 3D geometrical forms & 4 & 3 & $25 / 25 / 18$ \\
Study 2: organic decomposition & 4 & 3 & $26 / 26 / 26$ \\
Study 3: 'twice as' concept & 4 & 3 & $44 / 44 / 44$ \\
\hline
\end{tabular}

The pre-, post-, and delayed post-tests in the three learning studies were conducted in different ways. In study 1 , the children were tested in groups of two or three, with each child's performance being measured. In study 2, children were interviewed before and after the intervention, one by one. Finally, in study 3 , the pre- and post-tests were in written form and each child completed them individually (Table 4).

Table 4. Materials used and scores on the tests

\begin{tabular}{|c|c|c|}
\hline & Materials used for tests & $\begin{array}{l}\text { Numbers of questions/points per } \\
\text { question/maximum score }\end{array}$ \\
\hline $\begin{array}{l}\text { Study 1: 3D } \\
\text { geometrical forms }\end{array}$ & $\begin{array}{l}\text { Wooden blocks in four different } \\
\text { forms and colours }\end{array}$ & $\begin{array}{l}\text { No questions; } 1 \text { point if the child sorted three } \\
\text { blocks by the same geometrical form, tests } \\
\text { interrupted after } 10 \text { minutes }\end{array}$ \\
\hline $\begin{array}{l}\text { Study 2: organic } \\
\text { decomposition }\end{array}$ & $\begin{array}{l}\text { Apple, bread, and leaf in different } \\
\text { stages of decomposition }\end{array}$ & $9 / 0-2$ points each / 18 points \\
\hline $\begin{array}{l}\text { Study 3: 'twice as' } \\
\text { concept }\end{array}$ & $\begin{array}{l}\text { Printed booklet with drawings of } \\
\text { four different response options for } \\
\text { each question }\end{array}$ & $7 / 0-1$ points each / 7 points \\
\hline
\end{tabular}

All three projects were previously analysed concentrating on the children's learning (Landgren \& Svärd, 2013; Ljung-Djärf, 2013; Ljung-Djärf et al., 2013). The prior assessment of the children's learning is briefly summarized in Table 5.

Table 5. Assessment of the children's learning (mean results pre-, post-, and delayed post-test)

\begin{tabular}{llll}
\hline & Cycle A & Cycle B & Cycle C \\
\hline Study 1: 3D geometrical forms (no max. score) & $1.3 / 2.5 / 4.5$ & $1.7 / 1.7 / 2.2$ & $1.0 / 1.2 / 2.6$ \\
Study 2: organic decomposition (max. 18) & $7.9 / 8.9 / 8.9$ & $6.6 / 6.8 / 8.0$ & $8.5 / 10.9 / 11.7$ \\
Study 3: 'twice as' concept (max. 7) & $1.4 / 1.7 / 1.4$ & $1.2 / 1.3 / 1.8$ & $0.7 / 2.1 / 2.2$ \\
\hline
\end{tabular}




\section{Results}

For the purpose of this article, the projects were reanalysed to illustrate the process by which preschool teachers shifted their emphasis when participating in the projects. Throughout this process, verbatim transcripts, the results of each LS project, and the original video-recordings were studied and analysed in relation to each other to identify similarities concerning teachers' ways of handling content issues. In all studies, data were collected by observing planning meetings, video-recording lessons, and reading teachers' written reflections on the process. During the initial analysis, each project was summarized in terms of frame, focus, and teaching strategy (see Table 5).

Table 5. Summary of studies 1, 2, and 3 in terms of frame, focus, and teaching strategy

\begin{tabular}{|c|c|c|c|}
\hline & Cycle A & Cycle B & Cycle C \\
\hline \multirow[t]{3}{*}{$\begin{array}{l}\text { Study } \\
1\end{array}$} & Frame: play and activities & $\begin{array}{l}\text { Frame: geometrical forms in a playful } \\
\text { context }\end{array}$ & Frame: features of blocks \\
\hline & $\begin{array}{l}\text { Focus: feeling and touching } \\
\text { the forms, moving around and } \\
\text { being active }\end{array}$ & $\begin{array}{l}\text { Focus: showing and touching the } \\
\text { forms, using blocks }\end{array}$ & $\begin{array}{l}\text { Focus: correcting concepts, comparing } \\
\text { one form with another }\end{array}$ \\
\hline & $\begin{array}{l}\text { Strategy: distributing blocks to } \\
\text { children, moving when } \\
\text { teachers show a certain form, } \\
\text { finding everyday material of } \\
\text { the same forms }\end{array}$ & $\begin{array}{l}\text { Strategy: distributing blocks to } \\
\text { children, building houses and boats, } \\
\text { feeding robots with blocks }\end{array}$ & $\begin{array}{l}\text { Strategy: distributing one form after } \\
\text { another, naming them, describing them; } \\
\text { correcting children when they feed the } \\
\text { wrong robot by discussing why the block } \\
\text { did not fit the mouth (see Figure } 2 \text { ) }\end{array}$ \\
\hline \multirow[t]{3}{*}{$\begin{array}{l}\text { Study } \\
2\end{array}$} & $\begin{array}{l}\text { Frame: play, storytelling, } \\
\text { fantasy }\end{array}$ & $\begin{array}{l}\text { Frame: initial play then children's } \\
\text { own discovering }\end{array}$ & Frame: science presentation \\
\hline & $\begin{array}{l}\text { Focus: the hand-puppet and his } \\
\text { pretend picnic }\end{array}$ & $\begin{array}{l}\text { Focus: organic items and } \\
\text { decomposers }\end{array}$ & $\begin{array}{l}\text { Focus: contrast of fresh and partly } \\
\text { decomposed organic items }\end{array}$ \\
\hline & $\begin{array}{l}\text { Strategy: Children distinguish } \\
\text { organic decomposition using } \\
\text { play and fantasy; no answer is } \\
\text { commented on as right or } \\
\text { wrong. }\end{array}$ & $\begin{array}{l}\text { Strategy: Children distinguish } \\
\text { organic decomposition by touching, } \\
\text { smelling, seeing, and discovering } \\
\text { organic objects. They use science } \\
\text { concepts but seem uncomfortable } \\
\text { with them. Process follows the } \\
\text { children's own discoveries and tries } \\
\text { to put them into words. }\end{array}$ & $\begin{array}{l}\text { Strategy: Focus on critical aspects, using } \\
\text { scientific concepts. }\end{array}$ \\
\hline \multirow[t]{3}{*}{$\begin{array}{l}\text { Study } \\
3\end{array}$} & $\begin{array}{l}\text { Frame: initial play then } \\
\text { mathematical presentation }\end{array}$ & $\begin{array}{l}\text { Frame: initial play then mathematical } \\
\text { presentation }\end{array}$ & Frame: mathematical presentation \\
\hline & $\begin{array}{l}\text { Focus: a sum and twice as } \\
\text { many }\end{array}$ & $\begin{array}{l}\text { Focus: a sum and twice as many; } \\
\text { much, high, long }\end{array}$ & $\begin{array}{l}\text { Focus: the initial sum and twice as many } \\
\text { simultaneously }\end{array}$ \\
\hline & $\begin{array}{l}\text { Strategy: The teacher uses } \\
\text { wood blocks and selected } \\
\text { children to illustrate the } \\
\text { concept; the children suggest } \\
\text { solutions; if someone suggests } \\
\text { a wrong answer, the issue is } \\
\text { shifted to someone else. }\end{array}$ & $\begin{array}{l}\text { Strategy: The teacher presents a } \\
\text { problem and all children get wood } \\
\text { blocks to put in front of them. The } \\
\text { right response is noted but not } \\
\text { otherwise commented on. }\end{array}$ & $\begin{array}{l}\text { Strategy: The teacher presents a } \\
\text { problem; all children get red and blue } \\
\text { Lego pieces and a two coloured sheets of } \\
\text { paper. The red sheet and red Lego pieces } \\
\text { represent the initial sum, while the blue } \\
\text { ones represent 'twice as'. All answers are } \\
\text { commented on; those who give wrong } \\
\text { answers get help. }\end{array}$ \\
\hline
\end{tabular}

In sum, three main modes of change were discerned during the analysis: ways of framing the activity, perceiving learning, and conducting the learning activity.

\subsection{Ways of Framing of the Activity}

When planning the first intervention in each study, the teachers' first impulse was to introduce the object of learning by playing, acting, or inviting the children to join in a fantasy game. They were preoccupied with activities and organizational factors. Instead of carefully investigating aspects of the object of learning, they concentrated on inventing things they thought would be fun and would hold the children's attention.

The teachers from study 1 decided to use three activities in the first lesson, which was not really a lesson, but 
more of a 'circle time' (normal duration about 20 minutes). They started by handing out four different geometrical forms to each child, naming them and allowing the children to touch and feel the blocks. Then, the children who had a cubicle were supposed to move around when the teacher held up a cubicle and played the drum. The teachers' intention was to let the children move about while discerning a form. However, the drum and movement became the centre or attention of this activity, not the object of learning. After this activity, the teachers showed the children a big suitcase full of cans, boxes, and packages of different forms, which the children were to sort into four different piles; however, as the teachers had not designated clear areas for the piles of each form, the activity became slightly chaotic. After the intervention, the teachers themselves found that they needed to structure the learning time better, so they introduced four robots of different forms in cycle B (see Figure 2). These robots were giant geometrical blocks, eating blocks the same forms as they were. A game in which children could move about was still conducted in cycle B. It was not until cycle $\mathrm{C}$ that the teachers dropped the extra games and concentrated on the forms. It then became possible for the children to discern the critical aspects of the geometrical forms during the intervention. Notably, the children did not miss the extra games: for them the blocks and robots seemed sufficient.

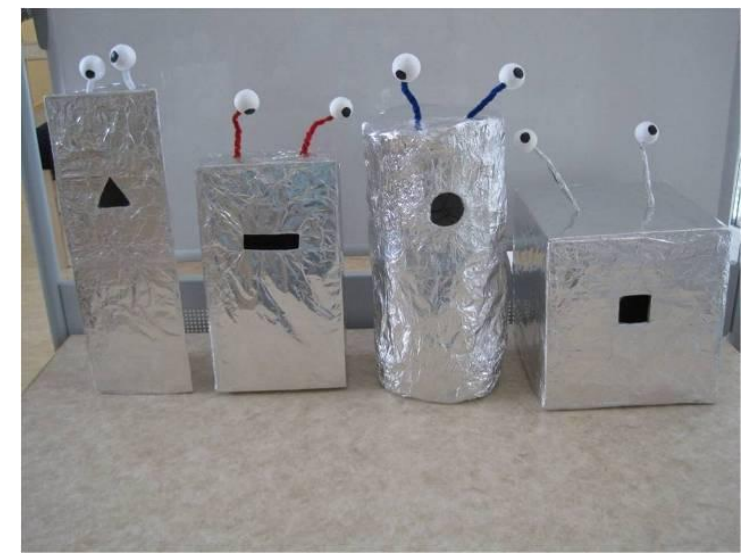

Figure 2. Robots used in study 1 (Landgren \& Svärd, 2013)

In study 2, it was decided that the first intervention should be designed as a dramatization based on a hand-puppet called Postman Pat and his pretend picnic in the forest. The teacher told an exciting story and the children participated by commenting and laughing. When arriving in the forest, the hand-puppet invited the children to participate in the picnic. Later, in a discussion of what would happen if the picnic leftovers were left in the forest, various suggestions were presented: 'a bird will eat the biscuit', 'a man will take it', 'it will blow away, and disappear under a tree', 'a troll is taking it', or 'it will remain forever'. The teacher was an interested listener but she did not try to direct the children's attention towards anything in particular, all answers being accepted as equal. As she (or the hand-puppet) had invited them to a fantasy game, the children took the opportunity to continue in that direction by fantasizing and suggesting solutions not related to science, such as trolls, witches, and magic men. In that way, acting and fantasy came to the foreground and the intended object of learning was displaced.

In addition, the first and second interventions in study 3 started with a well-known hand-puppet 'talking' to the children about the concept 'twice as'. He 'said' that he wanted the children to learn about this concept and that he wanted to sit beside them and watch and listen. The hand-puppet was then put away and the teacher illustrated 'twice as' by using small wood blocks and selected children. For example, the teacher said: 'Here, on this side there are three children. If I want twice as many on this other side, how many would it be?'

After the first intervention, in studies 2 and 3, it was proposed that the elements of play should be reduced, the initial emphasis instead being on decomposition and the mathematical concept. This was accepted somewhat reluctantly by the teachers, who particularly objected that the lesson might become 'too serious'.

To conclude, at the beginning of each study we found a fear of letting go of play and talking directly about the object of learning. Teachers also seemed uncertain of their ability to hold the children's attention if the activities were not introduced as exciting or special. They frequently invited children to take an active part in the activities or in play, for example, by interacting with the hand-puppet or taking part in a dramatization. However, when the lessons and the results of the pre-, post-, and delayed post-tests were analysed, teachers realized, after reflection, that playing and various activities did not necessarily promote learning, and gradually reduced the amount of play and activity time. 


\subsection{Ways of Perceiving Learning}

In each of the three analysed LSs we found clear traces of a 'doing culture' (Pramling Samuelsson \& Pramling, 2008), i.e., actively doing something is assumed to more or less automatically imply learning. During the first intervention in study 2 , the teachers tried to organize and present a situation related to the area of interest (i.e., organic decomposition) and assumed that the children would, more or less by themselves, concentrate on the intended object of learning and discern the intended message. The first intervention's pre- and post-tests made it clear that this was not occurring; instead, the children were talking about and clinging to playful explanations, for example, a witch or a magician was making the picnic leftovers disappear. In the second intervention in study 2, the teachers tried to place the initial focus of the lesson on decomposition. They dropped the idea of telling a story about the hand puppet Postman Pat and instead used a big box containing decomposers (woodlice) and various organic objects such as sticks, pumpkins, tomatoes, and cucumbers, fresh as well as partly decomposed, as the focus of the intervention. After a short dramatization ('Let's pretend we're going to the forest, and let's see what we can find there'), they 'found' the box and started to explore the contents with the children. The teachers noted the children's discoveries and questions, but used only a few questions of their own to direct the children's attention to the object of learning; the learning situation was largely governed by the children's interest and desire to discover. The children all appeared very interested in and focused on the activity. The teacher tried to respond to the children's various statements, which meant that the conversation often veered off towards things that had caught the children's momentary interest. The situation headed in various divergent directions (see excerpt 1) and it is difficult to discern a main focus.

\section{Excerpt 1}

Teacher: Yes, what can it be? [Pointing at something in the box]

Children: A woodlouse, woodlice.

Teacher: A woodlouse, yes.

Susanne: [Trying to catch the woodlice in the box] I can't.

Teacher: What does he do?

Pete: He is cutting.

Pam: $\quad$ You know, he is almost like a baby.

Teacher: Do you know what the woodlice like to eat? Do you know?

Steve: The babies are much smaller.

Jacob: Apples.

Teacher: $\quad$ Yes, they can eat apples.

Jacob: They think it is candy.

Teacher: $\quad$ They think it is candy? Yes, I can imagine that they think that apples are like candy.

Nils: $\quad$ There are a lot of insects.

Susanne: I can't see it anymore.

Teacher: I think that they eat such sticks, I think they like to eat the sticks. That's why they stay there [pointing at a small hole in the stick containing a woodlouse]. That's why they stay in the wood.

Fia: Look there [pointing at a woodlouse crawling around in the box].

Teacher: $\quad$ Yes, it is a woodlouse.

Nils: $\quad$ A woodlouse.

Fia: $\quad$ You can't hold a woodlouse, it is very dangerous.

Children: Nooooo, it is not dangerous.

In another example (study 1, cycle B) the teachers made very ambitious plans, with many activities that they had thought through carefully. Although the various activities themselves would not necessarily promote learning, the teachers were unaware of this when planning the intervention. However, in cycle B, right at the beginning of the lesson, one child said that blocks were good for building things; the teacher immediately abandoned the planned intervention and invited the child to build with the blocks. All the children built boats and houses for a while, until the next activity was introduced by the teacher. Afterwards, when evaluating the lesson, the teachers commented on this incident. They could see how their professional role had been too easily abandoned in following up on the children's ideas. 


\subsection{Ways of Conducting a Learning Activity}

In the discussions and planning before the interventions, teachers expressed a wish to broaden the children's language and introduce new concepts and specific words. However, during the interventions and in interaction with the children, this intention was difficult to realize. We could see a pattern of avoiding technical terms (e.g., decomposition and decomposers) or mathematical concepts or of using them with unease. The object of learning in study 1 was 3D geometrical forms. Talking about them and presenting them was impossible without naming them, as the names were also part of the object of learning. Naming something means that a phenomenon is manifested and can be talked about. Instead of pointing at a thing and saying 'that one', one can say 'the cubicle' and everyone knows what is meant. If the word cubicle is filled with meaning, the child can make a mental image of one, and can think about a cubicle even if one is not present. The intention was to use correct terms for the geometrical 3D forms, but in the first intervention with the children, the teacher went back to using 'simpler' words such as square instead of cubicle, or triangle instead of triangular prism, and even expressions such as 'one like this'. After the intervention, all the teachers talked about the issue and agreed to make a new effort in cycle $\mathrm{B}$, which they did with some progress. However, not until cycle $\mathrm{C}$ did the teacher use the correct terms all the time. It was also in cycle $\mathrm{C}$ that the children's patterns differed most between the pre- and post-tests.

Similar patterns were found in study 2 and to some extent in study 3 . The teachers in study 2 did not initially use terms such as decomposers or decomposition. Hence, they did not reflect on trying to conceptualize such things with the children. Later on, when the first intervention and the results of the first pre- and post-tests were analysed, it was clear that the children had had difficulties discerning the intended object of learning based on the implemented intervention. The teachers then discussed not making unnecessary simplifications related to the object of learning, and instead using appropriate words and trying to direct the children's attention to one aspect of the object of learning at a time. When using specific technical terms was suggested and discussed, the teachers were fairly doubtful. Later, when trying to use more specific language, it was clear that they did not initially feel comfortable using such language. However, for example, in cycle $\mathrm{C}$ in study 2 , they found out that many of the children picked up the technical words and used them by themselves when talking about the fresh and partly decomposed items shown to them by the teacher (Excerpt 2 ).

\section{Excerpt 2}

Teacher: Can you see there, there is a little bit of white [pointing at some white dots on a practically decomposed piece of wood].

Children: It is mould.

Teacher: Yes, it is mould, and if you look here [pointing at the piece of wood].

Kate: $\quad$ Mould.

Teacher: Yes, and let's look here, here, can you see something here?

Children: Yeees.

Teacher. Do you know what it is?

Sam: No.

Teacher: It looks like white threads. Do you know what that is, the white threads?

Bill: I don't know.

Ann: It is mould!

Teacher: Yes it is also mould. What then, does the mould do to the wood?

Ann: $\quad$ It makes the moisture disappear.

Teacher: What did the mould do to the tomatoes? And what is it doing to this piece of wood?

Ann: $\quad$ It makes it decomposed and rotten.

Kate: $\quad$ And then soil!

This discovery seemed to reassure the teachers and give them the courage to continue using a more content-oriented teaching style. It was also found, and later discussed, that the children's interest was not reduced by using such words. Instead, the children were actively participating, and the words seemed to have given them the tools they needed in order to participate.

\section{Discussion}

This article examines the process by which preschool teachers shifted their emphasis in preschool teaching during three LSs conducted in Swedish ECE. It is thus about the use of LS to challenge unexamined assumptions 
and develop tools useful for discussing and emphasizing ECE content, not instead of, but in addition to children's play. On one evaluation of an LS performed in an ECE context, a teacher wrote, 'It is as if I have made a gigantic pedagogical leap'. The teachers participating in our study expressed similar sentiments. Their comprehension of learning in an ECE context is no longer the same, and as they have been given the opportunity to experience and understand learning in a new way, they have also changed their practice. Play is no longer the first thing they plan for; instead, the object of learning is emphasized, as is how to design the learning situation to enable the children to discern that specific object. They have come to understand that a variety of activities can be pleasing, exciting, and interesting to children, including structured, methodical, and teacher-led activities not emphasizing play and fantasy.

What, more precisely, led to the shift in emphasis of the teachers' thinking about learning and teaching? We believe that two things were crucial. First, common assumptions were challenged. The results indicate that the three LSs revealed complications not anticipated by the teachers when play and activities were used as an essentially axiomatic way of framing teaching activities. The teachers were convinced that the children discerned the object of learning in the same way as the teacher did during the interventions, and were amazed when they saw the results of the initial post-tests, which indicated that this was not the case. The contrast between what they thought they had offered the children and what the children seemed to have experienced was an eye-opener. Such insights implied that the teachers had started to reflect on learning and found their earlier reasoning around learning to be unproblematized. It became obvious to them that playing is fine if nothing in particular is more important or emphasized than another, but that it is inadequate if a teacher wants children to discover and experience something in particular. They also became aware that the use of appropriate terms and concepts, such as decomposers, mould, and cubicle, did not reduce the children's interest, but instead seemed to give them tools with which to actively participate in the discussion and put the focused objects of learning into words.

Second, a theoretical tool was used. During the LS process, the teachers developed increased awareness and used variation theory as a tool for reflecting on and organizing their teaching activities. Although they, at least initially, expressed concerns that the lesson might become 'too serious', they later used variation theory concepts when analysing and talking about their teaching practice and the children's learning. The focus on the object of learning as a main principle of the theory also seemed helpful when they drifted towards merely entertaining the children. They became observant of their own and their colleagues' behaviour, and could conceptualize and support one another in adopting a more content-oriented way of planning and teaching.

An LS attempts to develop the teaching with the aid of variation theory concepts. The development and evaluation of the children's learning during the present LS was used as a methodological tool for reflecting on and improving teaching and learning. The object of the teachers' learning was a changed understanding of preschool learning. By means of our analysis and examples, we have tried to exemplify such changes. We argue, in line with Marton and Ramsden (1988), that 'If we want to change students' [in this case, teachers'] understanding, we have to deal with their present understanding in a methodical way' and that we 'have to know what view of a particular phenomenon we would like a learner to develop' (p. 272). In the analysed studies, the LS model indeed served as such a methodological tool reminding us 'of the important role of the teacher in designing learning experiences for students to make it possible for them to appropriate the object of learning' (Lo, 2012, p. 195). As mentioned above, the participating teachers expressed, in language and action, an increased awareness of preschool learning and this is the most essential outcome of our analysis. Such increased awareness includes the realization that a predetermined object of learning handled in a structured way can be interesting and exciting even for young children such as preschoolers. However, such a conceptual shift from a predominant emphasis on play and activities towards a view of preschool learning also emphasizing the intended object of learning focuses on both play and the object of learning, depending on the intention of each situation.

What then is the contribution of the present analysis of the use of the LS model in ECE practice? Comparing multiple similar projects made it clear that the process of shifted emphasis was similar throughout the three projects in terms of ways of framing the activity, perceiving learning, and conducting the learning activity. This finding reinforces results based on single projects (see, e.g., Holmqvist et al., 2012; Holmqvist et al., 2010, 2011, 2012; Ljung-Djärf, 2013; Ljung-Djärf et al., 2013) and strengthens previous promising results from the use of LS in the development of ECE practice.

\section{Acknowledgements}

We would like to thank the participating teachers who generously shared their time and teaching, and our research team Learning Design (LeaD) at Kristianstad University, Sweden, for encouragement and support.

\section{References}

Andrew, V. A. (2012). Using learning study to improve the teaching and learning of accounting in a school in 
Brunei Darussalam. International Journal for Lesson and Learning Studies, 1(1), 23-40. http://dx.doi.org/10.1108/20468251211179687.

Ailwood, J. (2003). Governing early childhood education through play. Contemporary Issues in Early Childhood, 4(3), 286-299.

Elliott, J. (1991). Action research for educational change. Buckingham: Open University Press.

Fleer, M. (2010). A cultural-historical perspective on play: Play as a leading activity across cultural communities. In I. Pramling Samuelsson \& M. Fleer (Eds.), Play and learning in early childhood settings (pp. 1-17). Dordrecht: Springer.

Fleer, M. (2011). Kindergartens in cognitive times: Imagination as a dialectical relation between play and learning. International Journal of Early Childhood, 43(3), 245-259. http://dx.doi.org/10.1007/s13158-011-0044-8.

Holmqvist, M. (2011). Teachers' learning in a learning study. Instructional Science, 39(4), 497-511. http://dx.doi.org/10.1007/s11251-010-9138-1.

Holmqvist, M., Brante, G., \& Tullgren, C. (2012). Learning Study in Pre-school. Teachers' awareness of children's learning and what they actually learn. The International Journal for Lesson and Learning Studies, 1(2), 153-167. http://dx.doi.org/10.1108/20468251211224190.

Holmqvist, M., Tullgren, C., \& Brante, G. (2010). Using variation theory to analyze what preschool children experience exemplified by wholes and parts as the object of learning. In J.V. Carrasquero, M. Holmqvist, D. McEachron, A. Tremante, \& F. Welsch (Eds.), Proceedings. Volume I (pp. 8-11). Orlando: International Institute of Informatics and Systemics.

Holmqvist, M., Tullgren, C., \& Brante, G. (2011). The object of learning: Before, during and after a learning situation. Journal of Systemics, Cybernetics and Informatics, 9(2), 67-73. http://www.iiisci.org/journal/CV\$/sci/pdfs/OL133KQ.pdf. Assessed December 12, 2011.

Holmqvist, M., Tullgren, C., \& Brante, G. (2012). Variation theory - a tool to achieve preschool curricula learning goals in Mathematics. Curriculum Perspectives, 32(1), 1-9.

Holmqvist Olander, M., \& Ljung-Djärf, A. (2013). Theoretical appropriation in pre-school teachers' expressions after in-service training. Creative Education, 4(7B), 11-16. http://dx.doi.org/10.4236/ce.2013.47A2003.

Landgren, L., \& Svärd, H. (2013). De yngrebarnenslärande [The younger children's learning] In. M. Holmqvist (Ed.), Learning study iförskolan[Learning study in preschool], (pp. 79-92). Lund: Studentlitteratur.

Lidholt, B. (2001). Integrationen förskoleklass, grundskola och fritidshem [Integration of preschool, primary school and recreation centres]. (Dnr. 98:2144). Stockholm: Skolverket.

Lillemyr, F.O., Søbstad, F., Marder, K., \& Flowerday, T. (2011). A multicultural perspective on play and learning in primary school. International Journal of Early Childhood, 43, 43-65.

Lewis, C. (2002). Lesson study: A handbook of teacher-led instructional change. Philadelphia, PA: Research for Better Schools, Inc.

Lo, M. L. (2012). Variation theory and the improvement of teaching and learning. Göteborg: Acta Universitatas Gothenburgensis.

Lo, M. L., \& Marton, F. (2012). Towards a science of the art of teaching: Using variation theory as a guiding principle of pedagogical design. International Journal for Lesson and Learning Studies, 1(1), 7-22. http://dx.doi.org/10.1108/20468251211179678.

Ljung-Djärf, A. (2013). The learning study process: A collaborative way to develop the use of contrast of critical aspects in preschool educational practice. Journal of Studies in Education, 3(1), 33-47. http://dx.doi.org/10.5296/jse.v3i1.2743.

Ljung-Djärf, A., \& Holmqvist Olander, M. (2013). Using learning study to understand pre-schoolers' learning: Challenges and possibilities. International Journal of Early Childhood, 45(1), 77-100. http://dx.doi.org/10.1007/s13158-012-0067-9.

Ljung-Djärf, A., Holmqvist Olander, M., \& Wennås Brante, E. (2013). Patterns of variation-a way to challenge and develop early childhood learning?: Concluding reflections from learning study projects conducted in Swedish early childhood education. Creative Education, 4(7A1), 33-42. http://dx.doi.org/10.4236/ce.2013.47A1005.

Ljung-Djärf, A., Magnusson, A., \& Peterson, S. (2013). From doing to learning: Changed focus during a pre-school learning study project on organic decomposition. International Journal of Science Education. Published online: 08 Aug 2013. http://dx.doi.org/10.1080/09500693.2013.822604. 
Marton, F., \& Booth, S. (1997). Learning and Awareness. Mahwah, NJ: Lawrence Erlbaum Associates.

Marton, F., \& Ramsden, P. (1988). What does it take to improve learning? In P. Ramsden, (Ed.), Improving Learning: New Perspectives, pp. 268-287. Kogan Page: London.

Olteanu, C., \& Holmqvist, M. (2012). Differences in success in solving second-degree equations due to differences in classroom instruction. International Journal of Mathematical Education in Science and Technology, 43(5), 575-587. http://dx.doi.org/10.1080/0020739X.2011.622807.

Olteanu, C., \& Olteanu, L. (2010). To change teaching practice and students' learning of mathematics. Education Inquiry, 1, 381-397.

Olteanu, C., \& Olteanu, L. (2012). Equations, functions, critical aspects and mathematical communication. International Education Studies, 5(5), 69-78. http://dx.doi.org/10.5539/ies.v5n5p69.

Pang, M. F. (2006). The use of learning study to enhance teacher professional learning in Hong Kong. Teaching Education, 17(1), 27-42. http://dx.doi.org/10.1080/10476210500527915.

Pang, M. F., \& Marton, F. (2005). Learning theory as teaching resource: Enhancing students' understanding of economic concepts. Instructional Science, 33(2), 159-191. http://dx.doi.org/10.1007/s11251-005-2811-0.

Pramling Samuelsson, I., \& Asplund Carlsson, M. (2003). Det lekande lärande barnet $i$ en utvecklingspedagogisk teori [The playing and learning child in a theory of developmental pedagogy]. Stockholm: Liber.

Pramling Samuelsson, I., \& Pramling, N. (2008). Didaktiska studier från förskola och skola [Didactic studies of preschool and school]. Malmö: Gleerups.

Pramling Samuelsson, I., \& Fleer, M. (Eds.) (2010). Play and learning in early childhood settings. Dordrecht: Springer.

Runesson, U., \& Gustafsson, G. (2012). Sharing and developing knowledge products from learning study. International Journal for Lesson and Learning Studies, 1(3), $245-260$. http://dx.doi.org/10.1108/20468251211256447.

Runesson, U., \& Mok, I. A. C. (2003). Discernment and the question' what can be learned'? In F. Marton \& A. Tsui (Eds.), Classroom discourse and the space of learning. Mahwah, NJ: Lawrence Erlbaum Associates.

Siu, I. Y. M. (2008). Learning study as an approach to teacher development in two primary schools. The Asia-Pacific Education Researcher, 17(1), 99-108.

Sommer, D., Pramling Samuelsson, I., \& Hundeide, K. (Eds.) (2009). Child perspectives and children's perspectives in theory and practice. Dordrecht: Springer.

Swedish National Agency for Education. (2004). Förskola i brytningstid. Nationell utvärdering av förskolan. Rapport 239, 2004. Stockholm: Fritzes.

Swedish National Agency for Education. (2010). Curriculum for the preschool, lpfö 98/2010. Stockholm: Fritzes.

Tang, C. L., \& Leung, B. W. (2012). Teaching Cantonese opera in a primary school: Enhancing learning effectiveness with the variation theory. International Journal for Lesson and Learning Studies, 1(3), 261-275. http://dx.doi.org/10.1108/20468251211256456.

The Swedish Research Council. (2011). Forskningsetiska principer inom humanistisk-samhällsvetenskaplig forskning [Ethic principles in social science research]. http://www.codex.vr.se/texts/HSFR.pdf. Assessed 7 February 2012.

Wood, K. (2013). A design for teacher education based on a systematic framework of variation to link teaching with learners' ways of experiencing the object of learning. International Journal for Lesson and Learning Studies, 2(1), 56-71. http://dx.doi.org/10.1108/20468251311290132.

Yoshida, M., \& Fernandez, C. (2004). Lesson study: A Japanese approach to improving mathematics teaching and learning. Mahwah: Lawrence Erlbaum Associates Inc.

Yuk, K. P. (2012). Critical conditions for pre-service teachers' learning through inquiry: The learning study approach in Hong Kong. International Journal for Lesson and Learning Studies, 1(1), 49-64. http://dx.doi.org/10.1108/20468251211179704.

\section{$(\mathrm{cc}) \mathrm{BY}$}

This work is licensed under a Creative Commons Attribution 3.0 License. 